\title{
Efficient inhibition of acrylamide formation in French fries by dipping in lactic acid solution before and after par- frying in a two-step procedure
}

\author{
Erik Slinde ${ }^{1 *}$, Anders Skrede ${ }^{2}, G_{\text {rethe Enersen }}^{3}$, Pernille Baardseth ${ }^{3}$, Hans Blom $^{3}$, Thea W Sundt ${ }^{3}$ and Grete Skrede ${ }^{3}$ \\ ${ }^{1}$ Faculty of Chemistry, Biotechnology and Food Science, Norwegian University of Life Sciences, NO-1433 Ås, Norway \\ ${ }^{2}$ Department of Animal and Aquacultural Sciences, Faculty of Biosciences, Norwegian University of Life Sciences, NO-1433 Ås, Norway \\ ${ }^{3}$ Nofima - Norwegian Institute of Food, Fisheries and Aquaculture Research, NO-1433 Ås, Norway
}

\begin{abstract}
Acrylamide is a carcinogenic, neurotoxic, and genotoxic compound formed from free asparagine and reducing sugars during frying or baking of food products. The potato products French fries and chips are substantial contributors to acrylamide intake. The aim of the present work was to study effects of lactic acid and other $\alpha$-hydroxy acids on acrylamide formation in French fries. Effective inhibition of acrylamide formation in French fries was obtained by short-time dipping in $0.4 \%$ solution of lactic acid before par-frying. It is suggested that the inhibitory effect on acrylamide formation is due to formation of a 6-ring ester-acid amine between the protonated $\alpha$-hydroxy acid and free asparagine. The highest efficiency was achieved by applying lactic acid solution in a two-step procedure with dipping before and after par-frying. This process can be adopted to industrial conditions by lactic acid dipping after blanching and thereafter by submerging the par-fried French fries in lactic acid solution directly after the fryer. Use of this technology will contribute to lower acrylamide levels and reduced consumer exposure from French fries.
\end{abstract}

\section{Introduction}

The occurrence of acrylamide in certain fried foods, such as potato chips and French fries and in baked cereal products, was first reported in 2002 by Tareke et al. [1]. Acrylamide is carcinogenic [2], cytotoxic [3], and neurotoxic [4], and is formed in Maillard reactions between free asparagine and reducing sugars such as glucose and fructose [58]. Acrylamide is created when foods like potatoes, bread, biscuits, cereals, and coffee beans, are subjected to temperatures above $120^{\circ} \mathrm{C}$ during cooking, deep-frying or roasting [9]. To ensure food safety, the prevailing legal regulation of the European Union implies a benchmark level of maximum $500 \mu \mathrm{g} / \mathrm{kg}$ of acrylamide in French fries [10].

A variety of methods have been shown to reduce the amount of acrylamide in French fries. Most procedures involve reduced time and temperature of cooking $[9,11,12]$, or reduced amounts of the main acrylamide precursors free asparagine and reducing sugars in potatoes through cultivar selection or agronomic factors [13-17]. Also, the levels of acrylamide precursors in potatoes may be reduced through genetic modification [8]. Other methods shown to reduce contents of acrylamide precursors include washing, soaking and blanching of the raw potatoes [18], use of microorganisms metabolizing free sugars and/or free asparagine [19-21], and use of asparaginase to hydrolyze free asparagine to aspartic acid [22,23]. Moreover, mitigating effects on acrylamide formation have been obtained by addition of amino acids other than asparagine to promote competing reactions or degradation of the acrylamide formed $[7,9,24,25]$, and by adding di- or trivalent cations to suppress the Maillard reaction [26]. A decrease in $\mathrm{pH}$ increases protonation and reduces reactivity of free asparagine and has been shown to reduce the formation of acrylamide [27-30].

Lactic, citric, and ascorbic acids have been shown to inhibit acrylamide formation $[9,23,28]$. They are all $\alpha$-hydroxy acids, i.e. having an a-hydroxy group adjacent to a carboxylic group. We hypothesize that the hydroxy group in a-position to the carboxyl group may contribute to reduction of acrylamide formation. The aim of the present research was to study effects of lactic acid and other $a$-hydroxy acids on acrylamide formation in French fries when used in dipping solutions for blanched potatoes. Main emphasis was devoted to effects of a two-step treatment involving dipping in lactic acid solution both before and after par-frying.

\section{Materials and methods}

\section{Materials}

Potatoes (Solanum tuberosum L.) from cultivars (cv) Asterix, Innovator and Peik were obtained from factory suppliers. The potato material reflected currently used raw material by industrial collaborators when the experiments were carried out. High oleic acid rapeseed oil and palm oil were used for deep-frying, also in parallel with the industry.

\section{Experiments}

Unless otherwise stated, experimental work was performed in the pilot plant at Nofima - Norwegian Institute of Food, Fisheries and Aquaculture Research. Raw potatoes were washed in water, peeled,

${ }^{\star}$ Correspondence to: Erik Slinde, Faculty of Chemistry, Biotechnology and Food Science, Norwegian University of Life Sciences, NO-1433 Ås, Norway, Tel: +4799538480; E-mail erik.slinde@nmbu.no

Key words: acrylamide, lactic acid, $\alpha$-hydroxy acids, French fries, two-step dipping Received: April 21, 2020; Accepted: June 08, 2020; Published: June 11, 2020 
and cut into $1 \times 1 \mathrm{~cm}$ sticks, approximately $5 \mathrm{~cm}$ long. The sticks were transferred to a container filled with enough tap water to cover the material until use. All experiments included batches of $200-250 \mathrm{~g}$. Each batch was blanched for $5 \mathrm{~min}$ in 51 water at $100^{\circ} \mathrm{C}$. The blanched batches were dipped in solutions of choice. Dipping solutions were made by weighing appropriate amounts of inhibitor into tap water. In the factory, lactic acid was pumped from a large reservoir into the dipping tank to achieve the decided concentration. In the pilot plant, all dipping solutions (I l) were heated to $60^{\circ} \mathrm{C}$ in a heating/drying cabinet (Air-O-Steam $^{\mathrm{TM}}$, Electrolux Professional, Pordenone, Italy) prior to use. As control, tap water was used for dipping in all experiments. The $\mathrm{pH}$ of dipping solutions was adjusted/measured prior to heating and dipping. After dipping and before par-frying, potato batches were dried at $60^{\circ} \mathrm{C}$ for $10 \mathrm{~min}$ in the cabinet. Par-frying was performed in a fryer $(10 \mathrm{l}$ oil) from Nuova Elframo, Model EB (Bergamo, Italy) at $185^{\circ} \mathrm{C}$ unless otherwise stated. Frying time was determined by sensory judgement of color, crispiness and texture of control samples. Par-fried batches were cooled, packed and frozen. For finish-heating, each batch was either deep-fried or baked by being placed centrally in a pan in the middle of a forced convection oven (Electrolux AB, Stockholm, Sweden). Baking was performed at $225^{\circ} \mathrm{C}$ as suggested by the industry. Samples were packed and frozen prior to acrylamide analyses. All acrylamide analyses were performed after finish-frying. Specific details for the various experiments are given below.

\section{Different compounds as acrylamide inhibitors}

Blanched potato sticks (cv Asterix) were dipped in solutions of $\mathrm{HCl}$, ethanol, butanol, formic acid, acetic acid, lactic acid, malic acid, or glycolic acid for $30 \mathrm{~s}$. Each dipping solution contained a single compound at $100 \mathrm{mM}$ concentration. Prior to use, the $\mathrm{pH}$ of the dipping solutions was adjusted ( $\mathrm{HCI}$ or $\mathrm{NaOH}$ ) to 2.29, the default $\mathrm{pH}$ value of $100 \mathrm{mM}(0.9 \%)$ lactic acid. Par-frying was performed in rapeseed oil at $185^{\circ} \mathrm{C}$ for $2 \mathrm{~min} 45 \mathrm{~s}$. Frozen par-fried samples were finish-heated by baking at $225^{\circ} \mathrm{C}$ for $7 \mathrm{~min}$.

\section{Dipping in $\alpha$-hydroxy acids}

Batches of blanched potato sticks (cv Peik) were dipped in $40 \mathrm{mM}$ solutions of lactic acid, malic acid, tartaric acid, citric acid, ascorbic acid, or glucono- $\delta$-lactone for $30 \mathrm{~s}$. The $\mathrm{pH}$ of each dipping solution was adjusted to a target $\mathrm{pH}=\mathrm{pKa}-1$ or below, corresponding to more than $90 \%$ not dissociated. Par-frying was performed in rapeseed oil at $185^{\circ} \mathrm{C}$ for $3 \mathrm{~min} 30 \mathrm{~s}$. Finish-heating by baking of the frozen samples was at $225^{\circ} \mathrm{C}$ for $7 \mathrm{~min}$.

\section{Different concentrations of lactic acid and tartaric acid}

Unpeeled, blanched potato boats (cv Peik) were obtained from an industrial French fry producer. The potato boats had been blanched at $90^{\circ} \mathrm{C}$ for $5 \mathrm{~min}$, followed by blanching at $84^{\circ} \mathrm{C}$ for $26 \mathrm{~min}$. The blanched material was cooled in water and transported to the pilot plant for further processing the next day. Dipping solutions were $40 \mathrm{mM}$ or 10 $\mathrm{mM}$ lactic acid or tartaric acid. Potato boats were dipped for $40 \mathrm{~s}$ and dried. Par-frying of the batches was performed at $185^{\circ} \mathrm{C}$ for 2 min 40 s. Frozen batches were thawed for 2 minutes on a rotating plate in a microwave oven at $800 \mathrm{~W}$ prior to finish-heating by baking at $225^{\circ} \mathrm{C}$ for $12 \mathrm{~min}$.

\section{Lactic acid as inhibitor with or without addition of calcium lactate (CaLa)}

Batches of blanched potato sticks (cv Peik) were dipped for $40 \mathrm{~s}$. The dipping solutions were $40 \mathrm{mM}(0.36 \%)$ lactic acid, $2.3 \mathrm{mM}(0.5 \%)$ calcium lactate $(\mathrm{CaLa})$ or a combination of $40 \mathrm{mM}$ lactic acid and 2.3 $\mathrm{mM}$ CaLa. No adjustments of $\mathrm{pH}$ were performed. Batches were parfried in palm oil for $2 \mathrm{~min} 40 \mathrm{~s}$ at $180^{\circ} \mathrm{C}$. Frozen samples were finishheated by baking at $225^{\circ} \mathrm{C}$ for $12 \mathrm{~min}$.

\section{Single or two-step dipping in lactic acid}

Batches of blanched potato sticks (cv Innovator) were subjected to one of three dipping sequences; i) dipping prior to par-frying and freezing, ii) dipping of frozen sticks after par-frying and with subsequent refreezing, iii) dipping both before and after par-frying followed by freezing. All treatments included $40 \mathrm{~s}$ in $44 \mathrm{mM}(0.4 \%)$ lactic acid. Par-frying was performed in rapeseed oil at $185^{\circ} \mathrm{C}$ for 2 min. Dipped, frozen sticks were shaken in a strainer for $10 \mathrm{~s}$ prior to the renewed freezing. Finish-frying was carried out in rapeseed oil at $185^{\circ} \mathrm{C}$ for $4 \mathrm{~min} 30 \mathrm{~s}$. A second part of this study was identical except for milder heating conditions; par-frying at $145^{\circ} \mathrm{C}$ for $4 \mathrm{~min}$, and finishfrying at $170^{\circ} \mathrm{C}$ for $4 \mathrm{~min} 30 \mathrm{~s}$.

\section{Analyses}

Acrylamide content was determined by an accredited method using defatting, acetonitrile extraction, precipitation of proteins, and filtration prior to LC-MS analysis [31]. Acrylamide was used as internal standard. The method was certified after ISO/IEC 17025:2005 and accredited after SWEDAC 1977. Limit of quantification (LOQ) was 10 $\mu \mathrm{g} / \mathrm{kg}$ and measurement uncertainty (MU) was $12 \%$. Results are given as analytical results $\pm \mathrm{MU} \mu \mathrm{g} / \mathrm{kg}$. $\mathrm{pH}$ was measured using a Methron $744 \mathrm{pH}$-meter (Methron AG, Hersau, Switzerland). The ratio between dissociated ( $\mathrm{A}^{-}$) and undissociated (HA) acids were calculated from the dissociation formula:

$$
\mathrm{pKa}=\mathrm{pH}+\log \left(\left[\mathrm{A}^{-}\right] /[\mathrm{HA}]\right)
$$

where $\mathrm{pKa}$ is the dissociation constant for the acid and the brackets describe the equilibrium concentration of the dissociated and undissociated acid.

Hydrochloric acid, lactic acid, malic acid, tartaric acid, ascorbic acid, acetic acid, butanol, citric acid, ethanol, formic acid, glucono- $\delta$ lactone, and glycolic acid were purchased from Sigma Aldrich (SaintLouis, MO, USA). Calcium lactate (CaLa) (PURACAL PP Food, Amsterdam, The Netherlands) was obtained from a commercial French fry producer. Structure of the most relevant compounds are given in Figure 1. All chemicals were analytical grade. Lactic acid was obtained as a solution containing at least $85 \%$ acid. Butanol, formic and glycolic acid were used as model components for chemical structure and were not intended for consumption. All other compounds are well known to occur in foods and are thus acceptable for application in industrial processing.

\section{Results and discussion}

Acrylamide content in French fries can be reduced by introducing inhibitors throughout processing from raw potatoes to final products ready for consumption. In industrial processing this may imply inhibitor use both before par-frying and prior to finish-heating. In the present study, the potential of different compounds in reducing acrylamide in French fries was studied partly in a pilot plant and partly in full industrial scale.

\section{Effects of different compounds on acrylamide formation}

Mechanisms involved in inhibition of acrylamide formation in French fries during processing were studied in a pilot plant by applying 
a selection of compounds with varying chemical structure, including an inorganic acid $(\mathrm{HCl})$, alcohols, and carboxylic acids (Figure 1) (Table 1). All batches were treated at identical conditions during par-frying, freezing, storage and finish-heating.

Use of $\mathrm{HCl}$ as an acidifier, representing a direct effect of lowered $\mathrm{pH}$, resulted in a substantial inhibition of acrylamide formation (64\%) when compared with water. This is in accordance with previous reports of effects of $\mathrm{pH}$ on acrylamide formation, although $\mathrm{pH}$ was higher than in our study $[9,32]$. The acidified alcohols had no inhibitory effect beyond the effect of $\mathrm{pH}$ alone. The organic acids with their carboxyl group, however, showed an additional inhibitory effect on acrylamide formation. The inhibitory effect of acetic acid confirms previous findings on reduced acrylamide formation by use of acetic acid in a potato model system [32].

The highest inhibitory efficiency among the compounds studied was demonstrated by the $a$-hydroxy acids lactic acid, malic acid, and glycolic acid, which lowered acrylamide levels by more than $80 \%$ compared with the control. The mitigating effect of lactic acid was confirmed in a test carried out by an industrial French fry producer, where dipping in $0.2 \%(22 \mathrm{mM})$ and $0.4 \%(44 \mathrm{mM})$ solutions resulted<smiles>C=CC(N)=O</smiles>

\section{Acrylamide}<smiles>O=C(O)CO</smiles>

Glycolic acid<smiles>O=C(O)CC(O)(C(=O)O)C(=O)O</smiles>

Citric acid<smiles>CC(O)C(=O)O</smiles>

Lactic acid<smiles>O=C1O[C@H]([C@H](O)CO)C(O)=C1O</smiles>

Ascorbic acid<smiles>NC(=O)C[C@H](N)C(=O)O</smiles><smiles>O=C(O)CC(O)C(=O)O</smiles>

Malic acid<smiles>O=C1OC(CO)C(O)C(O)C1O</smiles>

\section{Glucono-delta-} lactone<smiles>O=C(O)C(O)C(O)C(=O)O</smiles>

Tartaric acid

Figure 1. Chemical structure of acrylamide, asparagine and studied $\alpha$-hydroxy acids. All acids are in their undissociated form

Table 1. Effect of different compounds on acrylamide formation in French fries after dipping blanched potato sticks in $100 \mathrm{mM}$ solutions prior to par-frying

\begin{tabular}{|c|c|c|c|c|}
\hline Inhibitor & Functional group of inhibitors & pH & $\begin{array}{l}\text { Acrylamide } \\
(\mu \mathrm{g} / \mathrm{kg})\end{array}$ & $\begin{array}{c}\text { Inhibition }^{\mathrm{b}} \\
(\%)\end{array}$ \\
\hline Control (water) & & 7.60 & $270 \pm 32$ & 0 \\
\hline \multicolumn{5}{|l|}{ Inhibitor } \\
\hline Inorganic acid & $\mathrm{H}^{+}$ & & & \\
\hline $\mathrm{HCl}$ & & 2.29 & $96 \pm 12$ & 64 \\
\hline Alcohols & $\mathrm{R}-\mathrm{OH}$ & & & \\
\hline Ethanol & & 2.29 & $120 \pm 14$ & 56 \\
\hline Butanol & & 2.29 & $100 \pm 12$ & 63 \\
\hline Organic acids & $\mathrm{R}-\mathrm{COOH}$ & & & \\
\hline Formic acid & & 2.29 & $63 \pm 8$ & 77 \\
\hline Acetic acid & & 2.29 & $82 \pm 10$ & 70 \\
\hline$\alpha$-hydroxy acids & $\mathrm{R}-\mathrm{CH}(\mathrm{OH})-\mathrm{COOH}$ & & & \\
\hline Lactic acid & & 2.29 & $49 \pm 6$ & 82 \\
\hline Malic acid & & 2.29 & $42 \pm 5$ & 84 \\
\hline Glycolic acid & & 2.29 & $31 \pm 4$ & 89 \\
\hline
\end{tabular}

${ }^{a}$ Analytical results $\pm 12 \%$ measuring uncertainty.

'Inhibition as percent of control. 
in $62 \%$ and $74 \%$ inhibition of acrylamide formation, respectively. Our results confirm previous data on mitigation of acrylamide formation in French fries by a-hydroxy acids such as lactic acid and citric acid $[9,23,33]$. The presence of the hydroxy group in $\alpha$-position to the carboxyl group, apparently affects the reaction mechanisms involved in mitigation of acrylamide formation in French fries. This may explain why a-hydroxy acids were more efficient in reducing acrylamide formation than lowering of $\mathrm{pH}$ by $\mathrm{HCl}$, acetic acid or formic acid in our study.

There is a well-known relationship between non-enzymatic browning, acrylamide formation and color of French fries. In our study, we observed that the reduction in acrylamide concentration due to application of $a$-hydroxy acids correlated with a lighter and less golden color. French fries with lower levels of acrylamide may thus appear slightly different from current standard products and this may cause industrial reluctance in introducing new technologies. Acrylamide levels will increase if finish-frying practices in industry or households are carried out with extensively high temperature to achieve a more golden color [23,34]. However, according to recent studies the impact of color on consumer preferences may be dependent on the knowledge of acrylamide and its adverse effects on human health. When informed about the related health benefits consumers might choose French fries with light color [35].

\section{Effects of $\alpha$-hydroxy acids on acrylamide formation}

A preliminary experiment in our lab revealed that reduction of $\mathrm{pH}$ below the pKa value increased the inhibition efficiency of lactic acid against acrylamide formation in French fries. The inhibitory effects of different $\alpha$-hydroxy acids were studied at a $\mathrm{pH}$ about one unit below their pKa-values (pKa-1). This implies that at least $90 \%$ of the acids were in the undissociated form. All $a$-hydroxy acids except glucono$\delta$-lactone, showed substantial inhibitory effect against acrylamide formation (Table 2). Lactic acid exerted the highest inhibiting efficiency, but substantial inhibition of acrylamide formation was also obtained by dipping in solutions of malic acid, tartaric acid, citric acid, and ascorbic acid prior to par-frying. Glucono- $\delta$-lactone has an internal ring structure (Figure 1), and this may have hampered its ability to participate in reactions mitigating acrylamide formation. Inhibitory effects of lactic acid, citric acid, and ascorbic acid on acrylamide formation in French fries have been reported earlier [23,28,30].

\section{Effect of lactic acid and tartaric acid concentrations on acrylamide formation}

Among the studied $a$-hydroxy acids, lactic acid was the most efficient in reducing acrylamide, whereas tartaric acid has the lowest pKa-value and thus requires the lowest $\mathrm{pH}$ to be undissociated (Table 2). The next experiment was therefore limited to these two acids.

The effect of different concentration of lactic acid and tartaric acid on acrylamide formation was studied based on blanched potato boats from a French fry processing company. As shown in Table 3, the different acid concentrations affected $\mathrm{pH}$ and consequently the extent of dissociation. A low concentration of $10 \mathrm{mM}$ lactic acid had less inhibitory effect on acrylamide formation than $40 \mathrm{mM}$. This was even more pronounced with tartaric acid, where no inhibition was obtained with $10 \mathrm{mM}$ in the dip. At this concentration of tartaric acid, only 6.1 $\mathrm{mM}$ was undissociated and available for reaction with free asparagine.

Previous studies have shown free asparagine contents in potato cultivars between 14 and $68 \mathrm{mM}(1.8$ and $9.0 \mathrm{mg} / \mathrm{g}$ ) [36], and between 9 and $25 \mathrm{mM}$ [13]. Assuming that acrylamide inhibition is achieved by an equimolecular reaction between an a-hydroxy acid and free asparagine (Figure 2), the concentration of $10 \mathrm{mM}$ tartaric acid in the dipping solution was probably too low for efficient inhibition of acrylamide formation. Sufficient amounts of free asparagine may have been available for reacting with sugar to form acrylamide, and tartaric acid levels higher than $10 \mathrm{mM}$ would have been necessary for efficient inhibition of acrylamide formation.

Table 2. Effect of $\alpha$-hydroxy acids on acrylamide formation in French fries after dipping blanched potato sticks in $40 \mathrm{mM}$ solutions prior to par-frying

\begin{tabular}{|c|c|c|c|c|}
\hline & pKa & pH & Acrylamide $^{\mathrm{a}}(\mu \mathrm{g} / \mathrm{kg})$ & Inhibition $^{\mathrm{b}}(\%)$ \\
\hline Control (water) & - & 7.32 & $570 \pm 68$ & 0 \\
\hline \multicolumn{5}{|l|}{$\alpha$-hydroxy acids } \\
\hline Lactic acid & 3.86 & 2.69 & $250 \pm 30$ & 56 \\
\hline Malic acid & 3.46 & 2.42 & $300 \pm 36$ & 47 \\
\hline Tartaric acid & 3.04 & 1.91 & $340 \pm 41$ & 40 \\
\hline Citric acid & 3.14 & 1.99 & $310 \pm 37$ & 46 \\
\hline Ascorbic acid & 4.12 & 2.73 & $300 \pm 36$ & 47 \\
\hline Glucono- $\delta$-lactone & 3.70 & 2.24 & $510 \pm 61$ & 11 \\
\hline
\end{tabular}

${ }^{a}$ Analytical results $\pm 12 \%$ measuring uncertainty.

'Inhibition as percent of control.

Table 3. Effect of different lactic acid and tartaric acid concentrations on acrylamide formation in French fries after dipping blanched potato boats prior to par-frying

\begin{tabular}{|c|c|c|c|c|c|}
\hline & $\begin{array}{l}\text { Inhibitor concentration } \\
(\mathrm{mM})\end{array}$ & pH & Undissociated acid (\%) & Acrylamide $^{\mathrm{a}}(\mu \mathrm{g} / \mathrm{kg})$ & $\begin{array}{c}\text { Inhibition }^{\mathrm{b}} \\
(\%)\end{array}$ \\
\hline Control (water) & 0 & 8.02 & - & $1150 \pm 138$ & 0 \\
\hline \multicolumn{6}{|l|}{ Inhibitor } \\
\hline Lactic acid & 40 & 2.68 & 94 & $470 \pm 56$ & 59 \\
\hline Lactic acid & 10 & 3.03 & 87 & $700 \pm 84$ & 39 \\
\hline Tartaric acid & 40 & 2.30 & 80 & $810 \pm 97$ & 30 \\
\hline Tartaric acid & 10 & 2.70 & 61 & $1200 \pm 144$ & -4.3 \\
\hline
\end{tabular}

${ }^{a}$ Analytical results $\pm 12 \%$ measuring uncertainty.

'Inhibition as percent of control. 

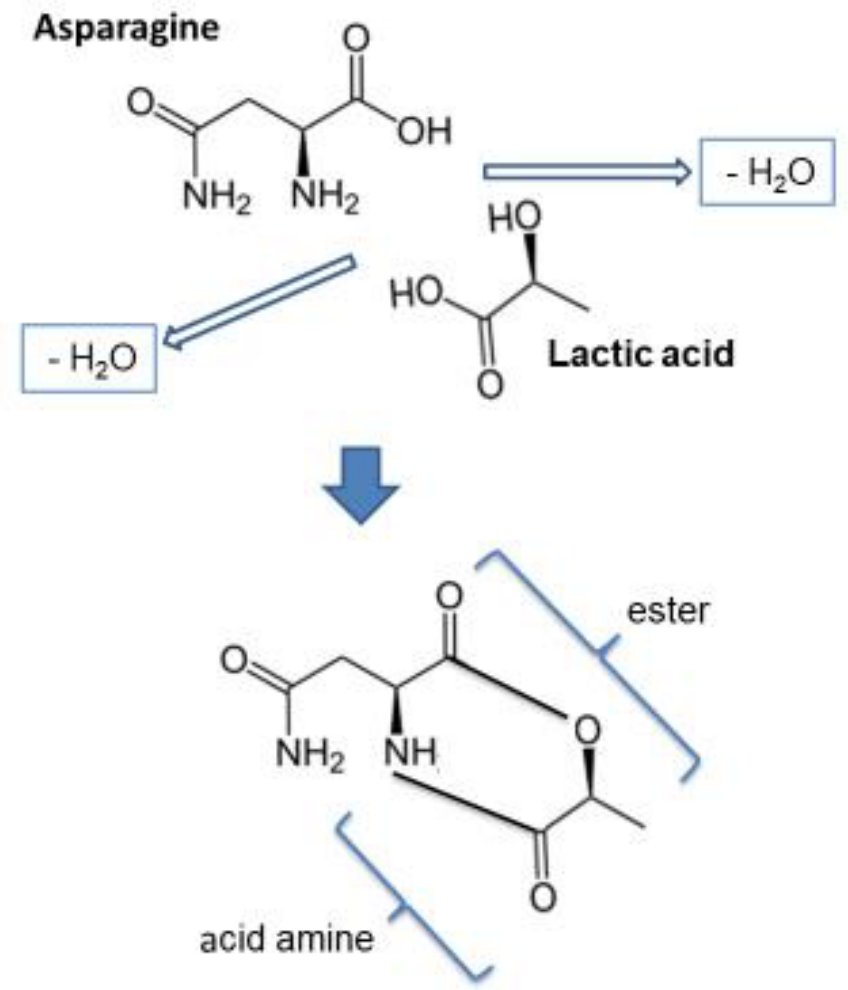

Figure 2. Suggested reaction mechanism for the formation of 6-ring ester-acid amine from asparagine and lactic acid at low $\mathrm{pH}$

\section{Inhibition of acrylamide formation by lactic acid in the presence of processing aids}

Industrial production of French fries commonly includes the use of processing aids like sodium acid pyrophosphate (SAPP) and calcium lactate (CaLa). The SAPP was not applied in our studies, but previous studies show that several organic acids reduce acrylamide formation even in the presence of SAPP [23]. Thus, the inhibiting effects of a-hydroxy acids on acrylamide formation obtained in our studies are of relevance also for industrial production with the widely used SAPP as processing aid. Treatment with SAPP may also by itself contribute to a minor reduction in acrylamide formation [33].

Use of CaLa in the production of frozen par-fried French fries has previously shown inconsistent effects on acrylamide concentration [23]. Furthermore, CaLa precipitates in the presence of SAPP, thus representing a potential problem in commercial production of French fries [37]. However, the $\mathrm{Ca}^{2+}$-ions from CaLa helps to provide crispier French fries by reacting with the pectin of the potatoes and the lactate may contribute to inhibition of acrylamide production. Table 4 shows results from our study applying CaLa in dipping solutions with and without lactic acid. The $\mathrm{Ca}^{2+}$-ions caused higher $\mathrm{pH}$ in the solution (7.63) and $\mathrm{CaLa}$ alone had minor effect on acrylamide formation. At this $\mathrm{pH}$, the lactic acid from the CaLa will be extensively dissociated and, thus, provide no inhibition of acrylamide formation. By adding $40 \mathrm{mM}$ lactic acid, the $\mathrm{pH}$ was lowered to 3.6 and the effect of the combined CaLa/ lactic acid solution on acrylamide inhibition was similar to sole lactic acid addition. At pH 3.6, greater amounts of undissociated lactic acid as well as protonated amino groups are present, and reactions between the two can occur. This indicates a positive effect of including both lactic acid and CaLa in the dipping solution when the $\mathrm{pH}$ is kept low.

\section{Inhibition of acrylamide by two-step dipping in lactic acid} solution, both before and after par-frying

The results from our experiments show substantial but variable reduction in acrylamide when raw potato sticks were passed through a bath containing an $\alpha$-hydroxy acid prior to par-frying, freezing, and finish-heating. The reason for this variation in extent of inhibition has not been revealed, but most likely relates to properties of the potato raw material $[5,6,38]$, and differences in frying conditions among our experiments.

As compared to lactic acid, no other $a$-hydroxy acids showed more convincing benefits in reducing acrylamide in our studies. Advantages of lactic acid include general approval by food regulatory authorities and consumer acceptance of a wide variety of fermented foods. A major industrial supplier of French fries has adopted lactic acid dipping as part of the standard procedure for 3 years. The company has had no consumer complaints about texture or acid taste and has considerably increased market share in this period.

During par-frying and freezing, more free asparagine may migrate to the outer area of the potato stick and a second treatment with lactic acid could generate further inhibition. An experiment was conducted to study a two-step approach where potato sticks were first treated in lactic acid solution ( $44 \mathrm{mM}, 0.4 \%)$ prior to drying, par-frying and freezing, and thereafter the frozen par-fried sticks were dipped again in lactic acid solution before finish-frying. As shown in Figure 3, single dipping in lactic acid solution, either before par-frying and freezing or by dipping of par-fried frozen sticks, both reduced acrylamide formation with about $40 \%$, whereas the combined treatment resulted in about $60 \%$ inhibition.

In a follow up study, the efficiency of the two-step approach was studied with two different combinations of temperature during parfrying and finish-frying (Table 5). The mildest temperature treatment was chosen to comply with the current EU regulations requiring that frying temperature should not exceed $175^{\circ} \mathrm{C}$ to avoid high acrylamide levels [10]. The two-step dipping procedure reduced acrylamide contents with $56 \%$ when using the highest frying temperature, whereas $72 \%$ reduction were achieved when applying the milder frying conditions. Accordingly, although the low-temperature frying was effective in reducing acrylamide formation, even further reduction could be obtained by applying the two-step lactic acid treatment.

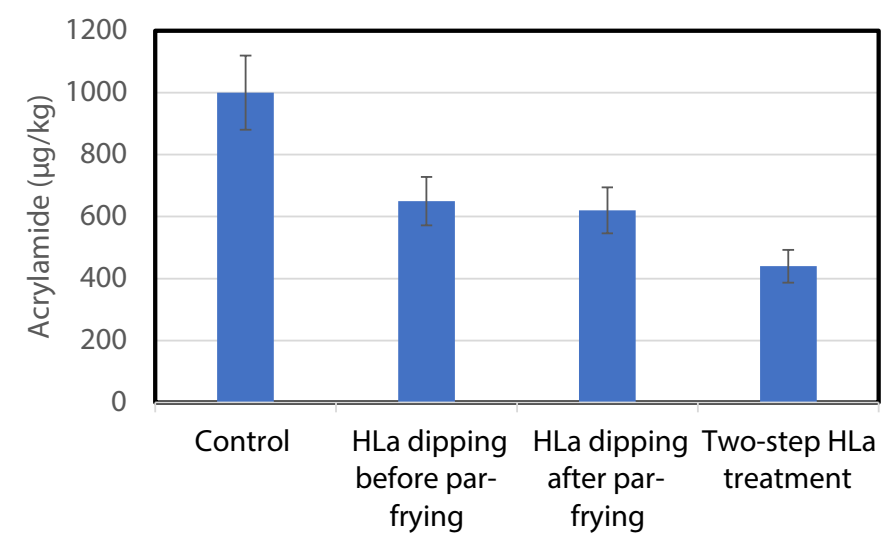

Figure 3. Acrylamide concentration $(\mu \mathrm{g} / \mathrm{kg})$ in French fries dipped in $44 \mathrm{mM}(0.4 \%)$ lactic acid (HLa) prior to par-frying, after par-frying, and by a two-step procedure with dipping both before and after par-frying. Analytical results $\pm 12 \%$ measuring uncertainty 
Table 4. Effect of lactic acid and calcium lactate $(\mathrm{CaLa})$ on acrylamide formation in French fries after dipping of blanched potato sticks prior to par-frying

\begin{tabular}{|l|c|c|c|c|}
\hline \multicolumn{1}{|c|}{ Sample } & CaLA & Lactic acid & pH & Acrylamide $(\boldsymbol{\mu g} / \mathbf{k g})$ \\
\hline Control (water) & 0 & 0 & 7.10 & $1085 \pm 130$ \\
\hline CaLa & $4.6 \mathrm{mM}(0.5 \%)$ & 0 & 7.63 & $1000 \pm 120$ \\
\hline Lactic acid & 0 & $40 \mathrm{mM}$ & 2.59 & $700 \pm 84$ \\
\hline CaLa + Lactic acid & $4.6 \mathrm{mM}(0.5 \%)$ & $40 \mathrm{mM}$ & 3.60 & 35 \\
\hline
\end{tabular}

${ }^{a}$ Analytical results $\pm 12 \%$ measuring uncertainty.

'Inhibition as \% of control.

Table 5. Effect of lactic acid on acrylamide formation in French fries processed at high or low temperatures after two-step dipping in $44 \mathrm{mM}$ solutions i.e. dipping before and after par-frying

\begin{tabular}{|c|c|c|c|c|c|c|c|}
\hline \multirow{2}{*}{ Treatment } & \multirow{2}{*}{$\mathbf{p H}$} & \multicolumn{2}{|c|}{ Dip prior to par-frying } & \multicolumn{2}{|c|}{ Dip after par-frying } & \multirow{2}{*}{$\begin{array}{c}\text { Acrylamide }^{\mathrm{a}} \\
\mu \mathrm{g} / \mathrm{kg}\end{array}$} & \multirow{2}{*}{$\begin{array}{c}\text { Inhibition }^{\mathrm{b}} \\
(\%)\end{array}$} \\
\hline & & Lactic acid & Par-frying & Lactic acid & Finish-frying & & \\
\hline \multicolumn{8}{|c|}{ High temperature } \\
\hline Control (water) & 7.10 & 0 & $185^{\circ} \mathrm{C}, 2 \mathrm{~min}$ & 0 & $180^{\circ} \mathrm{C}, 4 \min 30 \mathrm{~s}$ & $1000 \pm 120$ & \\
\hline Lactic acid & 2.62 & $44 \mathrm{mM}$ & $185^{\circ} \mathrm{C}, 2 \mathrm{~min}$ & $44 \mathrm{mM}$ & $180^{\circ} \mathrm{C}, 4 \mathrm{~min} 30 \mathrm{~s}$ & $440 \pm 53$ & 56 \\
\hline \multicolumn{8}{|l|}{ Low temperature } \\
\hline Control (water) & 7.10 & 0 & $145^{\circ} \mathrm{C}, 4 \mathrm{~min}$ & 0 & $170^{\circ} \mathrm{C}, 4 \min 30 \mathrm{~s}$ & $720 \pm 86$ & \\
\hline Lactic acid & 2.62 & $44 \mathrm{mM}$ & $145^{\circ} \mathrm{C}, 4 \mathrm{~min}$ & $44 \mathrm{mM}$ & $170^{\circ} \mathrm{C}, 4 \mathrm{~min} 30 \mathrm{~s}$ & $200 \pm 24$ & 72 \\
\hline
\end{tabular}

aAnalytical results $\pm 12 \%$ measuring uncertainty.

'Inhibition as percent of control.

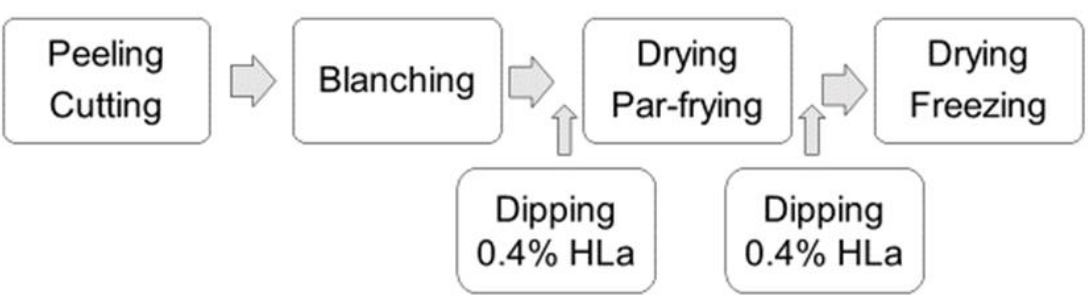

Figure 4. General lay-out of an industrial processing line with two-step lactic acid (HLa) treatment for mitigating acrylamide formation; dipping both before par-frying and after par-frying

To our knowledge, the beneficial effects of a two-step lactic acid dipping procedure have not been previously reported. This process can easily be adopted by the industry by adding lactic acid together with processing aids to the tank after blanching, and thereafter submerge the par-fried French fries in lactic acid solution directly after the fryer (Figure 4). This was tested in cooperation with an industrial supplier that applies lactic acid $(0.4 \%)$ dipping after blanching and prior to par-frying and freezing as standard processing procedure. The results obtained showed that dipping of the par-fried sticks directly from the fryer in $0.4 \%$ lactic acid reduced acrylamide levels after finish-frying from $510 \mu \mathrm{mol} / \mathrm{kg}$ to $76 \mu \mathrm{mol} / \mathrm{kg}$.

\section{Conclusion}

Acrylamide is established as a potential carcinogen in French fries, formed during high-temperature processing as an intermediate of Maillard reactions. Industrial practices to mitigate acrylamide formation include selection of potato varieties, seasonal adaptation of production and potato storage conditions, blanching of the potatoes, and lowering of frying temperature. Use of different additives have shown variable effects in lab-scale and industrial experiments. Our studies revealed efficient inhibition of acrylamide formation in French fries by short-time dipping in a $0.4 \%$ solution of $\alpha$-hydroxy acids at low $\mathrm{pH}$. The highest efficiency according to lab-scale studies and adopted industrial practices was obtained by applying a two-step lactic acid dipping procedure; first dipping before par-frying and thereafter a second dipping of the par-fried sticks. We suggest that the inhibitory effect of lactic acid and other $a$-hydroxy acids on acrylamide formation is due to formation of a 6-ring ester-acid amine between the protonated forms of the a-hydroxy acids and asparagine.

\section{Acknowledgments}

Financial support was provided by the Research Council of Norway through RFF-Vestlandet and Skattefunn. We acknowledge industrial support from Hoff SA, Gjøvik, Norway and Findus Norge AS, Tønsberg, Norway.

\section{References}

1. Tareke E, Rydberg P, Karlsson P, Eriksson S, Törnqvist M (2002) Analysis of acrylamide, a carcinogen formed in heated foodstuffs. J Agric Food Chem 50: 49985006. [Crossref]

2. Wang B, Guerette Z, Whittaker MH, Ator J (2020) Derivation of a no significant risk level (NSRL) for acrylamide. Toxicol Lett 320: 103-108. [Crossref]

3. Kacar S, Vejselova D, Kutlu HM, Sahinturk V (2018) Acrylamide-derived cytotoxic, anti-proliferative, and apoptotic effects on A549 cells. Hum Exp Toxicol 37: 468-474. [Crossref]

4. Matoso V, Bargi-Souza P, Ivanski F, Romano MA, Romano RM (2019) Acrylamide: A review about its toxic effects in the light of developmental origin of health and disease (DOHaD) concept. Food Chem 283: 422-430. [Crossref]

5. Zyzak DV, Sanders RA, Stojanovic M, Tallmadge DH, Eberhart BL, et al. (2003) Acrylamide formation mechanism in heated foods. J Agric Food Chem 51: 4782-4787. [Crossref]

6. Bethke PC, Bussan AJ (2013) Acrylamide in processed potato products. Am J Potato Res 90: 403-424.

7. Parker JK, Balagiannis DP, Higley J, Smith G, Wedzicha BL, et al. (2012) Kinetic model for the formation of acrylamide during the finish-frying of commercial French fries. J Agric Food Chem 60: 9321-9331. [Crossref]

8. Raffan S, Halford NG (2019) Acrylamide in food: Progress in and prospects for genetic and agronomic solutions. Ann Appl Biol 175: 259-281. [Crossref]

9. Rydberg P, Eriksson S, Tareke E, Karlsson P, Ehrenberg L, et al. (2003) Investigations of factors that influence the acrylamide content of heated foodstuffs. J Agric Food Chem 51: 7012-7018. [Crossref] 
10. European Commission (2017) Commission regulation (EU) 2017/2158 of 20 November 2017 establishing mitigation measures and benchmark levels for the reduction of the presence of acrylamide in food. Off J Eur Union 60: L 304/24-43.

11. Yang Y, Achaerandio I, Pujolà M (2016) Influence of the frying process and potato cultivar on acrylamide formation in French fries. Food Control 62: 216-223.

12. Tepe TK, Kadakal Ç (2019) Temperature and slice size dependences of acrylamide in potato fries. J Food Process Pres 43: e14270.

13. Halford NG, Muttucumaru N, Powers SJ, Gillatt PN, Hartley L, et al. (2012) Concentrations of free amino acids and sugars in nine potato varieties: Effects of storage and relationship with acrylamide formation. J Agric Food Chem 60: 1204412055. [Crossref]

14. Wang Y, Bethke PC, Bussan AJ, Glynn MT, Holm DG, et al. (2016) Acrylamideforming potential and agronomic properties of elite US potato germplasm from the national fry processing trial. Crop Science 56: 30-39.-

15. Muttucumaru N, Powers SJ, Elmore JS, Dodson A, Briddon A, et al. (2017) Acrylamide-forming potential of potatoes grown at different locations, and the ratio of free asparagine to reducing sugars at which free asparagine becomes a limiting factor for acrylamide formation. Food chem 220: 76-86

16. Novy RG, Whitworth JL, Stark JC, Schneider BL, Knowles NR, et al. (2017) Payette Russet: a dual-purpose potato cultivar with cold-sweetening resistance, low acrylamide formation, and resistance to late blight and potato virus Y. J Food Process Pres 94: 38-53.

17. Tran N, Barraj LM, Collinge S (2017) Reduction in dietary acrylamide exposure Impact of potatoes with low acrylamide potential. Risk Anal 37: 1754-1767. [Crossref]

18. Burch RS, Trzesicka A, Clarke M, Elmore JS, Briddon A, et al. (2008) The effects of low-temperature potato storage and washing and soaking pre-treatments on the acrylamide content of French fries. J Sci Food Agric 88: 989-995.

19. Baardseth P, Blom H, Skrede G, Mydland LT, Skrede A, et al. (2006) Lactic acid fermentation reduces acrylamide formation and other Maillard reactions in French fries. J Food Sci 71: C28-C33.

20. Di Francesco A, Mari M, Ugolini L, Parisi B, Genovese J, et al. (2019) Reduction of acrylamide formation in fried potato chips by Aureobasidum pulluans L1 strain. Int $J$ Food Microbiol 289: 168-173. [Crossref]

21. Koszucka A, Nowak A, Nowak I, Motyl I (2020) Acrylamide in human diet, its metabolism, toxicity, inactivation and the associated European Union legal regulations in food industry. Crit Rev Food Sci Nutr 60: 1677-1692. [Crossref]

22. Pedreschi F, Kaack K, Granby K (2008) The effect of asparaginase on acrylamide formation in French fries. Food Chem 109: 386-392. [Crossref]

23. Vinci RM, Mestdagh F, Van Poucke C, Kerkaert B, de Muer N, et al. (2011) Implementation of acrylamide mitigation strategies on industrial production of French Fries: challenges and pitfalls. J Agric Food Chem 59: 898-906. [Crossref]
24. Kim CT, Hwang ES, Lee HJ (2005) Reducing acrylamide in fried snack products by adding amino acids. $J$ Food Sci 70: C354-C358.

25. Zhu Y, Wang P, Wang F, Zhao M, Hu X, et al. (2016) The kinetics of the inhibition of acrylamide by glycine in potato model systems. J Sci Food Agric 96: 548-554. [Crossref]

26. Mariotti S, Pedreschi F, Carrasco JA, Granby K (2011) Patented techniques for acrylamide mitigation in high-temperature processed foods. Recent Pat Food Nutr Agric 3: 158-171. [Crossref]

27. Martins SIFS, Jongen WMF, van Boekel MAJS (2001) A review of Maillard reaction in food and implications to kinetic modeling. Trends Food Sci Tech 11: 364-373.

28. Jung MY, Choi DS, Ju JW (2003) A novel technique for limitation of acrylamide formation in fried and baked corn chips and in French fries. J Food Sci 68: 1287- 90.

29. De Vleeschouwer K, van der Plancken L, van Loey A, Hendrickx ME (2006) Impact of $\mathrm{pH}$ on the kinetics of acrylamide formation/elimination reactions in model systems. $J$ Agric Food Chem 54: 7847-7855.

30. Mestdagh F, Maertens J, Cucu T, Delporte K, Van Peteghem C, et al. (2008) Impact of additives to lower the formation of acrylamide in a potato model system through $\mathrm{pH}$ reduction and other mechanisms. Food Chem 107: 26-31.

31. Eurofins (2020) Acrylamide in foods. Method LidPest.0A.02.003. Eurofins Food \& Feed Testing Sweden Ab, Lidköping, Sweden.

32. Mestdagh F, Maertens J, Cucu T, Delporte K, Van Peteghem C, et al. (2008) Impact of additives to lower the formation of acrylamide in a potato model system through $\mathrm{pH}$ reduction and other mechanisms. Food Chem 107: 26-31.

33. Pedreschi F, Kaack K, Granby K, Troncoso E (2007) Acrylamide reduction under different pre-treatments in French fries. J Food Eng 79: 1287-1294.

34. Mesias M, Delgado-Andrade C, Holgado F, Morales FJ (2018) Acrylamide content in French fries prepared in households: A pilot study in Spanish homes. Food Chem 260: 44-52.

35. Johnson AM, Porter G, Camire ME (2019) Low-acrylamide French fry acceptance: A pilot study. J Food Sci 84: 3717-3725.

36. Kalita D, Holm DG, Jayanty SS (2013) Role of polyphenols in acrylamide formation in the fried products of potato tubers with colored flesh. Food Res Int 54: 753-757.

37. Vinci RM, Mestdagh F, De Meulenaer B (2012) Acrylamide formation in fried potato products - Present and future, a critical review on mitigation strategies. Food Chem 133: $1138-1154$

38. Seal CJ, de Mul A, Eisenbrand G, Haverkort AJ, Franke K, et al. (2008) Risk-benefit considerations of mitigation measures on acrylamide content of foods - A case study on potatoes, cereals and coffee. Br J Nutr 99: S1-S46. [Crossref]

Copyright: (C2020 Slinde E. This is an open-access article distributed under the terms of the Creative Commons Attribution License, which permits unrestricted use, distribution, and reproduction in any medium, provided the original author and source are credited. 